\title{
Study of Broiler Chicken Meat Quality in Different Traditional Markets in Sukoharjo Regency
}

\author{
Kiky Ayumasari ${ }^{1}$, Sri Sukaryani ${ }^{2}$, and Ludfia Windyasmara ${ }^{2}$ \\ ${ }^{1}$ Student of Program Study of Animal Science, Faculty of Agriculture, Universitas \\ Veteran Bangun Nusantara, Sukoharjo \\ ${ }^{2}$ Program Study of Animal Science, Faculty of Agriculture, Universitas Veteran \\ Bangun Nusantara, Sukoharjo \\ Corresponding author : Kiky Ayumasari \\ Email : kikiayuma4@gmail.com
}

\begin{abstract}
The aim of this study was to determine the quality of broiler chicken meat that sold at different traditional markets in Sukoharjo Regency. This study was conducted in the Laboratory Faculty of Agriculture, Animal Husbandry, Bangun Nusantara University Sukoharjo. This study was conducted in 2 weeks. The research method uses RAL (Completely Randomized Design) directional pattern. Then data was analyzed using by Anova (Analysiss of variance). The real effect of treatment was continued with the DMRT test (Duncan Multiple Range Test) to find out the differences between treatments. The observational parameters of the study include the $\mathrm{pH}$ levels test, water levels test, dissolved protein levels test, cooking loss levels and fat levels test. The results showed that different markets had no real effect $(\mathrm{P}>0,05)$ on the $\mathrm{pH}$ levels test, water levels test, cooking loss levels and have a real impact $(\mathrm{P}<0,05)$ on the dissolved protein levels test and fat levels test.
\end{abstract}

Keywords : Traditional Market; Quality of Meat; Broiler Chicken.

\section{Introduction}

Meat is one of the livestock products which is the largest supplier animal protein for the people in Indonesia. Beef, buffalo, lamb, goat, chicken and duck are some types of meat that are commonly consumed and processed into various foods by the people in Indonesia. Indonesian people mostly like chicken because besides it tastes good also have a high protein levels. Chicken meat as a food source has several other advantages such as the price is relatively affordable, can be consumed by the entire community, and sufficient supply is available in the market because it can be produced in a relatively short time.

Chicken meat usually supplied from broiler chicken meat. According to the data from Ministry of Trade (2014) consumption of broiler chicken meat Indonesia in 2013 amounted to $3.22 \mathrm{~kg} /$ capita/year, more than beef consumption that only 0.26 $\mathrm{kg} / \mathrm{capita} / \mathrm{year}$. The high demand because broiler chicken meat is a food that has a good nutritional levels for human needs. Low prices, good taste and smell, soft texture and 
easy to find on the market make this broiler chicken meat an alternative food that is liked by everyone. The chemical composition of broiler chicken meat consists of $18.6 \%$ protein, $15.06 \%$ fat, $65.95 \%$ water and $0.79 \%$ ash (Suradi, 2006).

Broiler chicken meat that sell in the market has varying quality. This quality is influenced by the condition of the livestock, how to care and the age of the animal. The various qualities of broiler chicken meat make the buyer must be careful when choosing the meat to be consumed. The indicators quality of broiler chicken meat include the $\mathrm{pH}$ levels, water levels, dissolved protein levels, cooking losses and fat levels from the meat. Another thing we can be applied when choosing meat is to attention the color and smell of the meat to get meat with good quality and avoid fraud such as meat mixing.

\section{Materials and Methods}

This study was conducted in the Laboratory Faculty of Agriculture, Animal Husbandry, Bangun Nusantara University Sukoharjo, for 2 weeks from February $5^{\text {th }}$ till $19^{\text {th }} 2020$. Broiler chicken meat used in the study was taken from the Cuplik market, Sukoharjo market and Mulur market in Sukoharjo Regency. Meat samples are taken from 5 seller in each market, with meat used as a sample is breast meat. The research method uses RAL (Completely Randomized Design) directional pattern. The treatments was 3 with 5 replications to get the experiment unit $3 \times 5 \times 2=30$ units of the experiment, among others :

$\mathrm{A}=$ Samples of Cuplik market broiler chicken meat

$\mathrm{B}=$ Samples of Sukoharjo market broiler chicken meat

$\mathrm{C}=$ Samples of Mulur market broiler chicken meat

The research variables observed were $\mathrm{pH}$ levelss (Bintoro and Sofyan, 2006), water levels (AOAC, 1995), dissolved protein levels (AOAC, 1995), cooking losses (Soeparno, 2009) and fat levels (AOAC, 1995).

\section{pH Levels}

Neutralize the $\mathrm{pH}$ meter first with aquades. Weigh the meat sample as much as 2 gram. Mash and mix with $10 \mathrm{ml}$ of aquades, then stir until homogeneous. Put the pHmeter into the sample and read the $\mathrm{pH}$ levels can be on the pHmeter screen.

\section{Water Levels}

Dry the bottle in the oven for 2 hours, then cool in a desiccator and weigh it. Weigh the meat as much as 2 gram, then put it in a bottle and weigh it again. Dry the cup containing the sample in the oven at $105^{\circ} \mathrm{C}$ for 24 hours until get a constant weight. Cool the bottle containing the sample in a desiccator and then weigh it again. Calculate the percentage of water levels using the formula:

Meat Water Levels $(\%)=\frac{\mathrm{W} 1-\mathrm{W} 2}{\mathrm{~W}} \times 100 \%$

Explanation : $\mathrm{W}=$ sample weight; $\mathrm{W} 1$ = initial weight; $\mathrm{W} 2$ = final weight.

\section{Dissolved Protein Levels}

Mash the meat sample as much as 2 gram and add $10 \mathrm{ml}$ of aquades, kemudian mengencerkan 1000x. Prepare 10 test tubes and fill each tube with $1 \mathrm{ml}$ of sample. Add 
$1 \mathrm{ml}$ of $\mathrm{D}$ solvent to each tube, then stir and incubate at room temperature for 15 minutes. Add $3 \mathrm{ml}$ of $\mathrm{E}$ solvent to each tube, then stir and incubate at room temperature for 45 minutes. Reading absorption of the sample at $\lambda 540 \mathrm{~nm}$ with a spectrophotometer. Determine dissolved protein levels with a standard curve equation.

\section{Cooking Loss Levels}

Weigh the meat sample as much as 10 gram, then put it in a polyethylene plastic bag and close it tightly. Boil the sample in a water bath at $80^{\circ} \mathrm{C}$ for one hour. Cool the boiled meat sample by putting it in a glass beker that filled with water for 15 minutes. Take out the sample from a plastic bag and dry it with tissue paper, and weighing again. Calculate the percentage of cooking loss using the formula: Meat Cooking Loss $(\%)=\frac{\mathrm{B} 1-\mathrm{B} 2}{\mathrm{~B} 1} \times 100 \%$

Explanation : $\mathrm{B} 1$ = initial wegiht; $\mathrm{B} 2$ = final weight.

\section{Fat Levels}

Weigh the sample as much as 2 gram, then dry it in the oven for 24 hours at $105^{\circ} \mathrm{C}$. Cool in a desiccator and weigh it. Wrap the sample in filter paper and weigh it again. Insert the sample into the distillation tools then do the filter with 10X circulation gasoline wash. Take out the sample to aerate and then dry it back in the oven for 6 hours at $105^{\circ} \mathrm{C}$. Cool the sample in a desiccator and weigh it again.

Meat Fat Levels $=\frac{\mathrm{w} 1-\mathrm{W} 2}{\mathrm{w}} \times 100 \%$

Explanation : $\mathrm{W}=$ dry sample weight; $\mathrm{W} 1=$ initial wegiht; $\mathrm{W} 2$ = final weight.

\section{Results and Discussion}

\section{pH Levels}

Table 1. Mean Test of Broiler Chicken Meat pH Levels in 3 Different Markets in Sukoharjo Regency

\begin{tabular}{cccc}
\hline \multirow{2}{*}{ Replications } & \multicolumn{3}{c}{ Treatments } \\
\cline { 2 - 4 } & $\mathrm{A}$ & $\mathrm{B}$ & $\mathrm{C}$ \\
\hline U1 & 6.05 & 6.00 & 6.00 \\
U2 & 5.90 & 5.95 & 5.70 \\
U3 & 5.85 & 5.80 & 6.00 \\
U4 & 6.10 & 5.80 & 6.20 \\
U5 & 5.90 & 6.05 & 6.20 \\
\hline Mean $^{\text {ns }}$ & 5.96 & 5.92 & 6.02 \\
\hline
\end{tabular}

Explanation $^{\text {ns }}$ : non signifikan

$\mathrm{pH}$ test results are presented in Table 1, results of the analysis showed that different markets did not significantly affect the $\mathrm{pH}$ levels of broiler chicken meat $(\mathrm{P}>0.05)$. The lowest meat $\mathrm{pH}$ levels obtained in treatment $\mathrm{B}$ was 5.92 and the highest was in treatment $\mathrm{C}$ it was 6.02. The results of this study are accordance with the Tobri's (2006) opinion which states that after death the meat becomes acidic so that the $\mathrm{pH}$ levels becomes 6 or smaller. The treatments showed pH levels of 6 and below 6 . 
Slaughtering time also affects the $\mathrm{pH}$ levels of meat because the distance from slaughtering time to selling meat make lower $\mathrm{pH}$ levels. The slaughter treatment $\mathrm{A}$ at 03.00 a.m , treatment B at 02.00 a.m and treatment $\mathrm{C} 04.00$ a.m. Based on results of the study it can be seen that treatments B has the lowest $\mathrm{pH}$ levels of 5.92, and treatment $\mathrm{B}$ has the earliest time for the slaughtering at 02.00 a.m.

\section{Water Levels}

Table 2. Mean Test of Broiler Chicken Meat Water Levels in 3 Different Markets in Sukoharjo Regency

\begin{tabular}{cccc}
\hline \multirow{2}{*}{ Replications } & \multicolumn{3}{c}{ Treatments } \\
\cline { 2 - 4 } & $\mathrm{A}$ & $\mathrm{B}$ & $\mathrm{C}$ \\
\hline U1 & 76.52 & 76.00 & 75.33 \\
U2 & 73.91 & 73.62 & 75.88 \\
U3 & 75.32 & 75.31 & 75.00 \\
U4 & 77.55 & 75.14 & 76.71 \\
U5 & 76.39 & 75.83 & 76.70 \\
\hline Mean $^{\text {ns }}$ & 75.94 & 75.18 & 75.92 \\
\hline
\end{tabular}

Explanation $^{\text {ns }}:$ non signifikan

Water levels results are presented in Table 2, results of the analysis showed that different markets did not significantly affect the water levels of broiler chicken meat ( $P>0.05)$. The lowest meat water levels obtained in treatment $\mathrm{B}$ was $75.18 \%$ and the highest in treatment A was $75.94 \%$. The results of this study are in accordance with the opinion of Aberle et al. (2001) which states that the water levels of broiler chicken meat is equal to $65 \%-80 \%$. Meat treatment $\mathrm{B}$ has a better quality compared to other treatment meat because it has the lowest water content, this is in accordance with the opinion of Hidajati (2005) which states that high water content in meat is one of the factors that support the development of fungi or microorganisms, meat with high quality must have low water content but high carcass percentage. Slaughtering time also affects meat water levels because according to Wala et al. (2016) chicken meat water levels will decrease during storage, decrease in chicken meat water levels because the water used by microbial to growth. The slaughter treatment $\mathrm{A}$ at $03.00 \mathrm{a} . \mathrm{m}$, treatment $\mathrm{B}$ at 02.00 a.m and treatment $C$ at 04.00 a.m. Based on the results of the study it can seen that treatments B has lowest water levels $75.18 \%$ and treatment B has average time of slaughter is the earliest at 02.00 a.m.

\section{Dissolved Protein Levels}

Dissolve protein levels results are presented in Table 3, the results of the analysis showed that different markets significantly affected the dissolved protein levels of broiler chicken meat $(\mathrm{P}<0.05)$. The lowest level of meat dissolved protein levels obtained in treatment $\mathrm{A}$ was $5.91 \%$ and the highest in treatment $\mathrm{C}$ was $8.12 \%$. The results of this study are not accordance with the opinion of Prasetyo et al. (2012) which states that the level of dissolved protein in broiler chicken meat between 9.49-11.92\%, but the treatments showed a percentage of meat dissolved protein levels between 
5.91\%-8.12\%. The difference can occur because age, nation, species, stress, feed and sex can cause differences in the chemical composition of meat (Lawrie, 2008). According to Tabiri et al. (2000) stress in livestock can trigger disruption of metabolic processes, especially in the digestion of nutrients, reduced nitrogen retention continues to decrease the digestibility of proteins and some amino acids, make the chemical quality of broiler meat is decrease.

Table 3. Mean Test of Broiler Chicken Meat Dissolved Protein Levels in 3 Different Markets in Sukoharjo Regency

\begin{tabular}{cccc}
\hline \multirow{2}{*}{ Replications } & \multicolumn{3}{c}{ Treatments } \\
\cline { 2 - 4 } & $\mathrm{A}$ & $\mathrm{B}$ & $\mathrm{C}$ \\
\hline U1 & 8.55 & 6.67 & 7.06 \\
U2 & 3.73 & 7.29 & 10.16 \\
U3 & 4.75 & 5.89 & 7.81 \\
U4 & 5.48 & 6.99 & 7.33 \\
U5 & 7.06 & 8.75 & 8.22 \\
\hline Mean & $5.91^{\mathrm{a}}$ & $7.12^{\mathrm{b}}$ & $8.12^{\mathrm{b}}$ \\
\hline
\end{tabular}

Explanation $^{\mathrm{a}, \mathrm{b}}$ : Different superscripts show real differences $(\mathrm{P}<0,05)$

Cooking Loss Levels

Table 4. Mean Test of Broiler Chicken Meat Cooking Loss Levels in 3 Different Markets in Sukoharjo Regency

\begin{tabular}{cccc}
\hline \multirow{2}{*}{ Replications } & \multicolumn{3}{c}{ Treatments } \\
\cline { 2 - 4 } & $\mathrm{A}$ & $\mathrm{B}$ & $\mathrm{C}$ \\
\hline U1 & 28.75 & 28.99 & 29.08 \\
U2 & 31.75 & 28.69 & 26.38 \\
U3 & 29.65 & 31.11 & 26.20 \\
U4 & 34.20 & 29.64 & 29.77 \\
U5 & 28.66 & 30.07 & 30.95 \\
\hline Mean $^{\text {ns }}$ & 30.60 & 29.70 & 28.48 \\
\hline
\end{tabular}

Explanation $^{\text {ns }}$ : non signifikan

Cooking loss levels results are presented in Table 4, results of the analysis showed that different markets did not significantly affect the cooking loss levels of broiler chicken meat $(\mathrm{P}>0.05)$. The lowest cooking loss levels in treatment $\mathrm{C}$ at $28.48 \%$ and the highest in treatment A was $30.60 \%$. The results of this study are in accordance with the opinion of Soeparno (2009) which states that the average value of cooking losses ranges from $15 \%-40 \%$. The treatments showed that percentage of cooking losses between $15 \%-40 \%$. Treatment $\mathrm{C}$ shows the lowest percentage of cooking losses is $28.48 \%$, it means that the quality of meat treatment $\mathrm{C}$ is better than other meat. This is accordance with the opinion of Soeparno (2009) which states meat with lower cooking losses has a better quality because it loses nutrients during cooking less. 


\section{Fat Levels}

Table 5. Mean Test of Broiler Chicken Meat Fat Levels in 3 Different Markets in Sukoharjo Regency

\begin{tabular}{cccc}
\hline \multirow{2}{*}{ Replications } & \multicolumn{3}{c}{ Treatments } \\
\cline { 2 - 4 } & $\mathrm{A}$ & $\mathrm{B}$ & $\mathrm{C}$ \\
\hline U1 & 2.55 & 1.62 & 3.08 \\
U2 & 2.30 & 2.96 & 3.22 \\
U3 & 3.07 & 2.93 & 4.54 \\
U4 & 2.92 & 3.02 & 3.83 \\
U5 & 2.55 & 3.56 & 2.84 \\
\hline Mean & $2.68^{\mathrm{a}}$ & $2.82^{\mathrm{a}}$ & $3.50^{\mathrm{b}}$ \\
\hline
\end{tabular}

Explanation $^{\mathrm{a}, \mathrm{b}}$ : Different superscripts show real differences $(\mathrm{P}<0,05)$

Fat levels results are presented in Table 5, the results of the analysis showed that different markets significantly affected the fat levels of broiler chicken meat $(\mathrm{P}<0.05)$. The lowest level of meat fat obtained in treatment A was $2.68 \%$ and the highest in treatment $\mathrm{C}$ was $3.50 \%$. The results of this study are accordance with the opinion of Aberle et al. (2001) which states that the range of chicken meat fat is $1.2 \%-12 \%$, the treatments showed a percentage of meat fat levels between $1.2 \%-12 \%$. Different treatments on meat of the study sample significantly affected the levels of meat fat. It is because fat is formed a result of the metabolism of the food eaten by chicken, chickens from different farms and using diverse feeds make the fat content produced also different. So that the metabolic process and nutrient digestion will affect the quality of the meat produced (Gregory, 2010).

\section{Conclusion}

Based on the results of the research above, it can be concluded that the quality of broiler chicken meat in 3 traditional markets in Sukoharjo Regency is included in both categories according to meat quality standards.

\section{References}

Aberle, E.D.J.C, D.E. Forrest, Gerrard and E.W. Mills. 2001. Principles of Meat Science. $4^{\text {th }}$ ed. W.H. Freman and Co, Sans Fransisco.

AOAC. 1995. Official Methods of Analysis. Association of Official Analytical Chemist, Washington D.C.

Bintoro, V.P. dan A. Sofyan. 2006. Daging ayam mati masih beredar luas. Wawasan, Jakarta.

Gregory, N.G. 2010. How Climatic Change Could Affect Meat Quality Food Res. Journal Foodres Vol 43 (7) : 1866-1873. 
Hidajati, N. 2005. Peran Bawang Putih (Allium sativum) dalam Meningkatkan Kualitas Daging Ayam Pedaging. Media Kedokteran Hewan Vol 21(1) : 32-34.

Kementrian Perdagangan. 2014. Analisis Outlook Pangan 2015-2019. Badan Pengkajian Dan Pengembangan Kebijakan Perdagangan. Kementerian Perdagangan, Jakarta.

Lawrie, R.A. 2008. Ilmu Daging Edisi ke-5 Penerjemah Prof. Dr. Aminuddin Parakkasi. Universitas Indonesia, Jakarta.

Prasetyo, E. A.M.P. Nuhriawangsa dan W. Swastike. 2012. Pengaruh Lama Perebusan terhadap Kualitas Kimia dan Organoleptik Abon dari Bagian Dada dan Paha Ayam Petelur Afkir. Jurnal Sains Peternakan Vol 10(2) : 108-114.

Soeparno. 2009. Ilmu Dan Teknologi Daging. Cetakan 5. Gadjah Mada University Press, Yogyakarta.

Suradi, K. 2006. Perubahan Sifat Fisik Daging Ayam Broiler Post Mortem Selama Penyimpanan Temperatur Ruang. Jurnal Ilmu Ternak Vol 6(1) : 23-27.

Tabiri, H.Y., K. Sato, M. Takashi, Y. Toyomizu and Akiba. 2000. Effect of Acut Heat Stress on Plasma Amino Acid Concentrations of Broiler Chickens. Japan Poult. 37: 86-94

Tobri, M. 2006. Kualitas Fisik Dan Organoleptik Daging Ayam Broiler yang Ransumnya diberi Penambahan Minyak Ikan yang Mengandung Omega-3. Skripsi Program Studi Teknologi Hasil Ternak. Fakultas Peternakan. Institut Pertanian Bogor, Bogor.

Wala, J., T. Ransaleleh, I. Wahyuni dan M. Rotinsulu. 2016. Kadar Air, Ph Dan Total Mikroba Daging Ayam Yang Ditambahkan Kunyit Putih (Curcuma mangga Val.). Jurnal Zootek Vol 36(2) : 405-416. 